\title{
Single center experience on talc poudrage morbidity: focus on high talc dosage
}

\author{
Giovanni Leuzzi ${ }^{1 *}$, Maria Letizia Vita', Venanzio Porziella', Maria Teresa Congedo ${ }^{1}$ and Alfredo Cesario ${ }^{1,2}$
}

\begin{abstract}
Malignant pleural effusion (MPE) is a common clinical problem of concern for most of the pneumologists and thoracic surgeons. A general consensus regarding the use of talc poudrage in treatment of MPE exists, but only few studies analyzed in detail talc insufflation related pulmonary morbidity. In particular, ARDS talc-related is caused by physical and chemical effects of the small talc particles (50\% particle size $<15 \mu \mathrm{m}$ ) and its occurrence is independent from the underlying disease, the quantity of talc used or the technique of talc instillation. In our series we observed 3 cases only (0.75\%) of talc-related lung injury. This data strongly confirm the low rate of talcrelated lung injury after talc poudrage in treatment of MPE regardless the amount of talc insufflated.
\end{abstract}

\section{Letter to the editor}

We read with great interest the report by Barbetakis et al [1] on morbidity, mortality and life expectancy following thoracoscopic talc insufflation. Malignant pleural effusion (MPE) is a common clinical problem of concern for most of the pneumologists and thoracic surgeons. In the US the annual incidence of MPE is estimated to be 250.000 cases and several studies suggest that exudative effusions are by large (42-77\%) caused by malignancy [2]. A general consensus regarding the use of talc poudrage in treatment of MPE exists, only few studies analyzed in detail talc insufflation related pulmonary morbidity. The most common side effects are pleuritic chest pain and mild fever. However very serious and potentially fatal adverse events, albeit unusual (1 to 9\% in published series [3]), as such as an adult respiratory distress syndrome (ARDS), can happen and these are related to the physical and chemical effects of the small talc particles $(50 \%$ particle size $<15 \mu \mathrm{m}$ ).

The occurrence of ARDS is, in fact, independent from the underlying disease, the quantity of talc used or the technique of talc instillation but it's strongly related to talc particle size. A greater alveolarearterial oxygen gradient in the group exposed to non-graded talc at $48 \mathrm{~h}$

\footnotetext{
* Correspondence: gio.leuzzi@yahoo.it

'Department of Thoracic Surgery, Catholic University of Sacred Heart, Rome, Italy

Full list of author information is available at the end of the article
}

after pleurodesis was detected when matched with that of those exposed to graded talc [4].

In our department, in the period between 01/95 and $10 / 10$, we performed thoracoscopic talc pleurodesis in 401 patients with MPE. As previously reported in our data [5], we performed a "single access" technique in those cases with no evidence of pleural adhesions or loculated effusions (241 patients), while 160 patients underwent a standard thoracoscopy. We routinely used an average of 4 grams (range 2-28 grams) of largeparticle asbestos-free talc pneumatically atomized through a soft silicone tube. To be specified that the upper range (up to 28 grams) was reached in those cases (15 patients) with high (up to $500 \mathrm{ml} /$ die) flow. In our series we observed 3 cases only $(0.75 \%)$ of talcrelated lung injury (acute respiratory failure in 2 cases and acute pulmonary edema in 1 patient). Our complication rate is lower to that reported in [1] (acute respiratory failure in 7 cases and reexpansion pulmonary edema in 1 patient), although the Authors have denied a correlation between talc insufflation and pulmonary complications. As well, differently from the evidence reported by Montes et al [6], we did not observe any complications in the 15 cases insufflated with more than 8 grams of talc.

Our results confirm the low rate of talc-related lung injury after talc poudrage in treatment of MPE regardless the amount of talc insufflated. We would really appreciate the Authors' reflection and reaction in
C Biomed Central

() 2011 Leuzzi et al; licensee BioMed Central Ltd. This is an Open Access article distributed under the terms of the Creative Commons Attribution License (http://creativecommons.org/licenses/by/2.0), which permits unrestricted use, distribution, and reproduction in any medium, provided the original work is properly cited. 
considering and discussing about high-dose (over $8 \mathrm{~g}$ ) graded-talc pleurodesis.

\section{Acknowledgements}

none

\section{Author details}

'Department of Thoracic Surgery, Catholic University of Sacred Heart, Rome, Italy. ${ }^{2} \mathrm{CdC}$ San Raffaele Velletri, Rome, Italy.

\section{Authors' contributions}

GL conceived the study, collected data and drafted the manuscript. MLV reviewed the pertinent literature. VP and MTC helped with bibliography. AC critically revised the paper. All authors read and approved the final version of the manuscript

\section{Competing interests}

The authors declare that they have no competing interests.

Received: 26 April 2011 Accepted: 27 June 2011

Published: 27 June 2011

\section{References}

1. Barbetakis N, Asteriou C, Papadopoulou F, Samanidis G, Paliouras D, Kleontas A, Lyriti K, Katsikas I, Tsilikas C: Early and late morbidity and mortality and life expectancy following thoracoscopic talc insufflation for control of malignant pleural effusions: a review of 400 cases. J Cardiothorac Surg 2010, 5:27.

2. Anon : Management of malignant pleural effusions. Am J Respir Crit Care Med 2000, 162:1987e2001.

3. Sahn SA, Light RW: Pro/con editorial: talc should/should not be used for pleurodesis. Am J Respir Crit Care Med 2000, 162:2023-6.

4. Maskell NA, Lee $Y C$, Gleeson FV, et al: Randomized trials describing lung inflammation after pleurodesis with talc of varying particle size. Am $J$ Respir Crit Care Med 2004, 170:377e82.

5. Margaritora S, Cesario A, Vita ML, Granone P: Single versus multiple access video-assisted thoracic surgery in the treatment of malignant pleural effusion. Eur J Cardiothorac Surg 2007, 32(2):397, author reply 397-8. Epub 2007 Jun 13.

6. Montes JF, Ferrer J, Villarino MA: Influence of Talc Dose on Extrapleural Talc Dissemination after Talc Pleurodesis. Am J Respir Crit Care Med 2003, 168:348-55

doi:10.1186/1749-8090-6-87

Cite this article as: Leuzzi et al: Single center experience on talc poudrage morbidity: focus on high talc dosage. Journal of Cardiothoracic Surgery 2011 6:87.

\section{Submit your next manuscript to BioMed Central and take full advantage of:}

- Convenient online submission

- Thorough peer review

- No space constraints or color figure charges

- Immediate publication on acceptance

- Inclusion in PubMed, CAS, Scopus and Google Scholar

- Research which is freely available for redistribution

Submit your manuscript at www.biomedcentral.com/submit
Biomed Central 